\title{
The Existence Of PT Jamsostek In Social Security Services For Participant Time Working Agreements (PKWT) ( Study at PT Jamsostek (Persero) Belawan Branch)
}

\section{Jones Parapat}

North Sumatera University Faculty Of Law. E-mail: jonesparapat@gmail.com

\author{
ARTICLE INFO \\ Keywords: \\ Social Security Services, Time \\ Working Agreements
}

Article history:

Received Jan 01, 2020;

Revised Feb 03, 2020;

Accepted Mar 13, 2020;

Online Apr 30, 2020.

\begin{abstract}
One of the rights inherent in human nature and existence is the right to social security. Therefore it is often argued that social security is a universal/general program that must be implemented by all countries. In the 1948 United Nations Universal Declaration of Human Rights Article 22 and Article 25 it is stated that: "Everyone, as a member of society has the right to social security: in the event of unemployment, illness, disability, inability to work, widowhood, old age" . Social security includes labor social security programs which are generally intended to provide protection and welfare for workers. There is no exception for workers based on a Specific Time Work Agreement which basically has different characteristics both in the implementation of their work and in terms of wages which emphasizes more on the Work Agreement agreed between the worker/laborer and the entrepreneur and the term of the working relationship is not permanent as is the case with to permanent workers/labourers. Because of these different characteristics, the regulation also needs to be regulated in a separate regulation, namely the Decree of the Minister of Manpower Number KEP- 150/MEN/1999 concerning the Implementation of the Social Security Program for Workers for Casual Daily Workers, Wholesale and Specific Time Work Agreements.The implementation of the social security program for workers based on a Specific Time Work Agreement (PKWT) in its implementation often does not work as expected which is able to provide protection and welfare / peace of mind for PKWT workers so that the authors are interested in raising this issue as a problem in the thesis. entitled "The Existence of PT Jamsostek (Persero) in Social Security Services for Workers with a Specific Time Work Agreement (PKWT)". This research is expected to be able to answer how the implementation of the labor social security program for PKWT workers, and find out what efforts can be made to ensure the protection of the Labor Social Security for PKWT workers, This research was conducted using library research and field research methods to obtain material as a reference in writing related to the problems of writing this thesis which in the end was able to provide benefits for various related parties in order to provide protection and welfare for workers. work especially for workers based on a Specific Time Work Agreement which in the end can play an active role in increasing economic growth for the welfare of the community and the future development of the nation.
\end{abstract}

This is an open access article under the CC BY-NC license. 


\section{Introduction}

Human rights in principle are a set of rights that are inherent in the nature and existence of humans as creatures of God Almighty and are His gift that must be respected, upheld by the State, law, government and everyone for the sake of honor and protection of human dignity.

In line with the current development of globalization and demands for reform as well as a prolonged economic crisis, employment problems are also growing. This is marked by increasing unemployment, demands for freedom of association, increasing strikes/demonstrations, increasing number of industrial relations disputes and job terminations, resulting in an unfavorable investment climate.

The participation of workers/laborers in national development is increasing, with the risks, responsibilities and challenges it faces. Therefore, they feel the need to provide protection, maintenance, and improvement of their welfare so that in turn they will be able to increase work productivity.

Workers Social Security is intended to provide protection for workers against socio-economic risks that befall workers in carrying out their work in the form of work accidents, illness, old age, or death. Thus, it is hoped that the peace of work for workers will be realized, so that productivity will increase.

It is undeniable that the increasing number of workers with different working relationships, faster industrial movements, the use of technology in industrial activities as well as other obstacles such as the occurrence of the global crisis, have consequences that can result in increasing problems that can disrupt company stability and national stability in general. Employment issues are still a sensitive issue that must be handled seriously/sincerely in good faith by all parties concerned ${ }^{4}$. Therefore, attention to the protection and improvement of the welfare of workers needs to be increased and a harmonious relationship between the actors of industrial activities, namely workers and employers, also needs to be maintained. Because basically workers and employers have the same position and the law has also guaranteed this equality, but sometimes law enforcement is often one-sided. "The law had made him equal, but man has not.

The work protection referred to above is protection for workers who work for employers who work in a business field in the form of a social protection for workers as regulated in Law Number 3 of 1992 concerning Workers' Social Security.

Labor Social Security is a basic community need because it involves the survival of both the workers themselves and the families of the workers. However, it is recognized that the Social Security for Workers (JAMSOSTEK) is currently a need that gets priority for the community considering its very important role in social protection for the community in general and workers in particular. State intervention in labor matters is a very important factor in modern labor law.

Article 1 number 2 of Law Number 3 of 1992 concerning Labor Social Security states that a Worker is any person who is able to do work both inside and outside the employment relationship in order to produce goods and services to meet the needs of the community. While Article 1 number 2 of Law number 13 of 2003 concerning Manpower defines Manpower as every person who is able to do work to produce goods and/or services both to meet their own needs and for the community further.

The definition of entrepreneur according to Law Number 13 of 2003 concerning Manpower is:

a. An individual, partnership or legal entity that runs a self-owned company; 
b. Individuals, partnerships or legal entities that independently run a company that is not theirs;

c. An individual, partnership or legal entity residing in Indonesia represents the company as referred to in letters a and b which is domiciled outside the territory of Indonesia.

Every employee is always at risk of a work accident which can result in total and/or partial disability so that the worker and his income are also terminated. Workers can also suffer from illness ranging from mild to severe and must receive treatment in hospital. Of course, this condition requires financing which will increase the burden on the worker's life, especially if a worker is the breadwinner in his family and gets an accident until he dies, his income is stopped and the family left behind will lose the source of income which is a source of livelihood for their family.

The risks mentioned above do not rule out the possibility that every worker will always face them because they are general in nature, so this needs to be dealt with in a systematic, planned and orderly manner so that it is very necessary to provide protection to workers through a program called Labor Social Security. Workers' Social Security is an effort to overcome these socio-economic risks because it will cover all types of work relationships such as permanent workers, casual daily workers, wholesalers and certain time work contracts/agreements (PKWT).

Article 1 point 1 of Law Number 3 of 1992 concerning Workers' Social Security defines Labor Social Security as a protection for workers in the form of compensation in the form of money as a partial replacement of lost or reduced income and services as a result of events or conditions experienced by workers. workers in the form of work accidents, illness, pregnancy, childbirth, old age and death.

The Manpower Social Security Program is a form of economic and social protection. It is said so because this program provides protection in the form of compensation in the form of money for reduced income and protection in the form of treatment/medication when a worker is exposed to certain risks. ${ }^{8}$. In order to provide legal protection and socio-economic protection for workers, especially in this case for workers based on a certain time work agreement that is different from other forms of labor, the Jamsostek program is organized which is implemented through an insurance system. Every worker has the right to the social security of the workforce which must be carried out by every company that does work in an employment relationship. This is no exception for workers based on work agreements for a certain time, which currently many employers choose as a form of employment relationship that is felt to be more profitable for the entrepreneur. In essence, the labor social security program is intended to provide certainty of the ongoing flow of family income as a replacement for part or all of the lost income. Labor social security educates workers' independence so that workers do not have to ask for the mercy of others if there are risks in the employment relationship due to the employment relationship.

Thus, to ensure the implementation of the social security program for workers, including for workers based on a work agreement for a certain time, an organizing body in the form of a State-Owned Enterprise is appointed based on a statutory regulation which in carrying out its functions and duties prioritizes services to the public. participants in order to improve the protection and welfare of workers and their families and in this case, based on PP No. 36 of 1995 concerning the Establishment of the Social Security Program Organizing Body for Workers, PT Jamsostek (Persero) was appointed as the organizing body for the Workers' Social Security program which provides basic protection to meet the minimum needs for workers and their families, by providing certainty of the ongoing flow of family income as a partial or complete replacement of lost income due to social risks and ultimately being able to play an active role in increasing economic growth for the welfare of the community and the future 
development of the nation.

\section{Method}

In the preparation of this thesis, a descriptive normative legal research method was used. In the context of writing this thesis the author tries to collect primary data and secondary data to complete the completion of this thesis and in this case the author collects data with two methods, namely:

a. Library Studies (Library Research)

Literature study basically serves to show the way to solve research problems. Briefly, literature study can help researchers to get an overview or information about similar research and related to the problems studied and get the problem solving approach used. ${ }^{13}$.

Research with this method through reading sources related to the problems faced in order to obtain the necessary data and materials that are scientific-torical in nature that can be used as material in writing this thesis.

b. Field Study (Field Research)

Research using this method can be done by collecting data, both primary data and secondary data, and materials obtained directly through research in the field. In this case the author conducted interviews with PT Jamsostek (Persero) to provide information about the data and materials needed in writing this thesis.

\section{Analysis and Results.}

\subsection{Jamsostek for Workers With Spesific Time Work Agreement (PKWT) According to} Minissterial Decree No. KEP-150/MEN/1999

Worker with a Specific Time Work Agreement has its own characteristics, for example in terms of wages which emphasize more on the Work Agreement agreed between the worker/laborer and the entrepreneur and the term of the working relationship is not fixed as is the case with permanent workers/labor. In view of these exceptions, the implementation of the Manpower Social Security program for its workers also requires special and separate rules.

In principle, every worker must be protected by the Jomsostek program. Provisions regarding this matter are contained in Article 4 paragraph (1) of Law Number 3 of 1992 concerning Workers' Social Security which reads: "The labor social security program as referred to in Article 3 must be carried out by every company for workers who carry out work in an employment relationship in accordance with the provisions of this Law".

Then the explanation of Article 4 paragraph (1) of Law Number 3 of 1992 states: "What is meant by workers who carry out work in an employment relationship are people who work in every form of business (company) or individuals by receiving wages including daily labor. freelance, piecework and contract (Specific Time Work Agreement) Given that labor social security is the right of the workforce, this provision emphasizes that every company or individual is obliged to implement it". Article 1 point 1 of the Decree of the Minister of Manpower of the Republic of Indonesia Number KEP-150/MEN/1999 of 1999 concerning the Implementation of the Manpower Social Security Program for Casual Daily Workers, Wholesale and Specific Time Work Agreements states: Labor social security is a protection for workers in the form of compensation in the form of money as a partial replacement of lost or measured income and services as a result of events or conditions experienced by workers in the form of work accidents, illness, pregnancy, maternity, old age and death.

While article 1 number 4 states: 
Workers who work based on a certain time work agreement, hereinafter referred to as workers with a certain time work agreement, are workers who work for entrepreneurs to do certain jobs by receiving wages based on an agreement in an employment relationship for a certain time and or completion of certain jobs.

Every worker who works based on a work agreement for a certain time, as well as permanent workers is entitled to social security for workers. On the other hand, every entrepreneur who employs workers with a certain time work agreement is required to include his workforce in the labor social security program to the Organizing Agency. ${ }^{77}$ which in this case is carried out by PT Jamsostek (Persero). The labor social security program as mentioned above includes work accident insurance, death insurance, old age insurance and health care insurance.

The procedure for registration of employment participation in a Specific Time Work Agreement for the labor social security program to the Organizing Body is in accordance with the provisions of the Regulation of the Minister of Manpower Number PER-05/MEN/1993 concerning Technical Instructions for Participation Registration, Payment of Contributions, Payment of Compensation and Social Security Services for Workers. Work.

The procedure for payment of contributions for the participation of casual daily workers, piece workers and work agreements for a certain time is carried out in accordance with the provisions of Government Regulation Number 14 of 1993 concerning the Implementation of Social Security for Workers and Regulation of the Minister of Manpower Number PER05/MEN/1993 concerning Technical Instructions for Participation Registration. , Payment of Contributions, Payment of Compensation, and Social Security Services for Workers by using the forms as contained in Attachments VII, VIII, IX and X of the Decree of the Minister of Manpower of the Republic of Indonesia NUMBER KEP-150/MEN/1999 of 1999 concerning the Implementation of the Social Security Program for Workers Employment for Freelance Herian Workers, Wholesale and Specific Time Work Agreements.

Supervision of the implementation of the labor social security program for employees of this Specific Time Work Agreement is carried out by the Labor Inspector. Employers who have organized their own health care program with better benefits as stipulated in the Regulation of the Minister of Manpower Number PER-01/MEN/1998 concerning the Implementation of Basic Health Care for Workers' Social Security, are not required to include their workforce in health care insurance to the Organizing Body.

In article 19 of the Decree of the Minister of Manpower Number KEP-150/KEP/1999 of 1999, it is stated that the supervision of compliance with this Ministerial Decree is carried out by the labor inspector. The supervision carried out by the supervisors mentioned above, which in this case is the Ministry of Manpower, can still be said to be ineffective which is still passive or still waiting. This may be due to the lack of awareness of employers in registering the participation of the company and each of its workers and the wrong assumption from employers that the Jamsostek program only wastes the company's money without significant benefits to the workforce and the company.

In addition, the organizers, in this case PT Jamsostek, do not have the right to directly supervise every company that has casual daily workers, wholesalers, contracts to register their workers into the existing workforce social security program, but based on article 19 of the Ministerial Decree No. KEP-150/MEN/1999 who has the right to carry out supervision is the Manpower Supervisory Employee, so that PT Jamsostek only records every entrepreneur who registers or reports every worker to PT Jamsostek for that there is a need for more coordination with the government in this case the Ministry of Manpower Work and its implementation must also be able to run well. 
The Jamsostek program is a government program that aims to provide protection for workers and their families which can only be implemented properly if the government in this case the Ministry of Manpower conducts guidance and supervision of compliance with the provisions of these laws and regulations.

The form of supervision carried out should be by conducting a direct review of the company to see the state of the workforce and asking directly to the workforce about the implementation of Jamsostek in the company. Thus, the workforce feels protected and thus achieves the national goal of creating a just and prosperous society.

\subsection{Jamsostek Claim Procedure}

\section{a. Claim Procedure for Health Care Insurance}

As already mentioned, health care insurance is intended to increase the productivity of the workforce so that they can carry out their duties as well as possible and constitute a health effort in the field of healing (curative). Health care insurance is given to the workforce or a legal husband or wife and a maximum of 3 (three) children aged 21 (twenty one) years old and unmarried or not working.

The scope of health care insurance services in the form of health care insurance packages includes:

1) First-rate outpatient services

2) Advanced outpatient services

3) Inpatient services

4) Pregnancy check-up and delivery assistance

5) Diagnostic support

6) Special service

7) Emergency services (emergency)

The claim procedure for obtaining services for the Health Care Insurance (JPK) includes :

1) Outpatient services at the first level of PPK

a) Participants choose the first-level health service provider they want.

b) Every time participants perform health services, they must show a health care card.

c) If further examination is required, the participant is referred to the designated advanced level health service provider

2) Outpatient services at the advanced level

a) Participants bring a referral letter and health care card to an advanced level health service provider to get services.

b) If consultation with other departments or diagnostic support is required, the specialist will provide a referral letter.

c) If a referral to another hospital is required, the specialist will provide a referral letter.

d) if the participant gets a prescription, it can be taken at a pharmacy that has been referred by the local PT Jamsostek (Persero).

3) Inpatient services

a) Participants who will be hospitalized must bring:

b) For participants who need emergency services, they can go directly to the hospital without the need for a referral letter.

c) If the delivery cannot be handled by the first-level health service provider or maternity home, the participant can be served at the maternity hospital by showing a referral letter from the first-level PPK.

3.3 Obstacles Faced by PT Jamsostek (Persero) in the Implementation of Social Security Services for PKWT Workers 
In carrying out its functions and duties as the implementing agency for the labor social security program, of course PT Jamsostek (Persero) has obstacles in implementing the program which basically provides protection for workers and creates welfare for workers. These obstacles can come from PT Jamsostek (Persero) itself or from outside PT Jamsostek (Persero) which is outside the capacity of PT Jamsostek (Persero) as the Organizing Agency appointed by the government to organize a social security program for workers, including for workers. workers who work under a Specific Time Employment Agreement.

\section{b. Analysis of PKWT Workforce Participation Data}

Workers with Specific Time Work Agreements are types of workers who work on an agreement in an employment relationship to do certain jobs and a certain time. More specifically, as previously mentioned, PKWT Workers are workers who work for employers to do certain jobs by receiving wages based on an agreement in an employment relationship for a certain time and or completion of certain jobs.

From the data obtained through interviews with PT Jamsostek (Persero) Belawan Branch Office, that the number of workers in the city of Medan is 731,374 people (While the number of workers in North Sumatra is 5,540,263 people ${ }^{96}$ ). Of the 731,374 workers in the city of Medan, the registered workforce as Jamsostek participants is 206,279 people (the active workforce is 58,038 people and the non-active workers are ${ }^{97}$ as many as 148,241 people). The number of workers who work under a Specific Time Work Agreement (PKWT) is 34,834 people and the number of workers with a Specific Time Work Agreement registered as Jamsostek Participants in Medan City is 17,750 people. The number of companies in the city of Medan are 1,217 companies and those registered as participants in the Jamsostek program are 962 companies with details of 649 companies actively participating and 313 companies participating in nonactive.

Table 1. List of interviews with PT Jamsostek (Persero) Belawan Branch Office is as follows:

\begin{tabular}{ll}
\hline \multicolumn{1}{c}{ DESCRIPTION } & \multicolumn{1}{c}{ AMOUNT } \\
\hline Workers in North Sumatra & $5,540,263$ people \\
Labor in Medan & 731,374 people \\
Workers registered as Jamsostek participants in Medan & 206,279 people \\
PKWT workers in Medan & 44,834 people \\
PKWT workers who are registered as Jamsostek participants in & 17,750 people \\
Medan & \\
Companies in Medan City & 1,217 companies \\
Companies registered as Jamsostek participants in Kota & 962 company \\
Medan & (649 active) \\
Companies that are not registered as participants in Jamsostek in & 255 companies \\
Indonesia & \\
Medan City (Potential Target) & \\
\hline
\end{tabular}

From the table above, it can be seen that the percentage of PKWT workers registered as Jamsostek participants in Medan City is $39.59 \%$ of the total 44,834 people (17,750 / 44,834 x $100 \%=39.59 \%$ ). And the percentage of companies that register companies and their workforce as participants in the Jamsostek program in Medan City is 75.62\% (962 / 1,272 x 100\% $=75.62 \%$ , and only $53.32 \%(649 / 1,217 \times 100 \%=53,32 \%)$ companies that are active as participants in the Jamsostek program.

The number of companies that organize their own health care insurance packages for their workers are 57 companies. In general, the reason for employers to provide their own health 
care insurance services for their workers is to provide better health services for their workers. Whereas based on the results of a review conducted by PT Jamsostek (Persero), there are several companies that provide health care insurance services themselves, but do not provide better services than those provided by the Organizing Agency (PT Jamsostek).

From the data obtained in the field, it can be seen that the percentage of the number of companies registering participation in the Jamsostek program tends to be very small, at $53.32 \%$ of companies. Likewise, the participation of PKWT workers who get protection as participants in the Jamsostek program is $39.59 \%$. In view of this, PT Jamsostek (Persero) has a tough task as the Organizing Agency for the Manpower Social Security Program to provide protection and welfare for all workers, especially in this case PKWT workers and their families, only reaching $39.59 \%$ protected their right to social security.

So far, PT Jamsostek (Persero) has made various efforts to increase participation in the social security program for workers, including for PKWT workers who have only reached $39.59 \%$, including:

1) conduct socialization to all companies (which can be reached) both to companies that have become participants in the Jamsostek program and to companies that have not become Jamsostek participants. perform follow-up by sending letters to companies that have not registered the company and its workforce as participants in Jamsostek.

2) following up on companies that ignore PT Jamsostek's call to register participation in the Jamsostek program with the Labor Inspectorate appointed by the Ministry of Manpower and Transmigration.

3) conduct a joint visit between PT Jamsostek (Persero) and the Manpower Superintendent of the Ministry of Manpower and Transmigration (Depnakertrans) to companies both registered and unregistered as participants in the Jamsostek program.

\section{Conclusion}

The Manpower Social Security Program is a form of economic and social protection because basically this program provides protection in the form of compensation in the form of money for reduced income and protection in the form of treatment/medication when a worker is exposed to certain risks. Every worker has the right to the social security of the workforce which must be carried out by every company that does work in an employment relationship. No exception for workers based on a certain time work agreement. To provide legal protection and socio-economic protection for workers based on a certain time work agreement (PKWT) which is different from other forms of labor, Then the Social Security Program for Workers is held, the implementation of which is carried out with an insurance system, which is specifically regulated in Ministerial Decree No. KEP-150/MEN/1999 of 1999 concerning the Implementation of the Social Security Program for Workers for Freelance, Wholesale and Temporary Work Agreements. . The labor social security program as mentioned above includes work accident insurance, death insurance, old age insurance and health care insurance.

The protection of the labor social security program for workers with a Specific Time Work Agreement (PKWT) will only work well if there is good coordination between employers as employers who are obliged to provide protection to the people they command, workers as people who do work on the basis of orders from employers to receive wages, as well as the government as labor inspectors considering that labor law has a very broad and important scope so that it requires government intervention in its implementation and supervision. In providing protection for the implementation of labor social security for the workers of the Specific Time Work Agreement (PKWT), Employers should have a high awareness to provide labor rights in accordance with applicable regulations. On the part of the workforce themselves, in the context of law enforcement, workers in individual activities or in joint activities should make an appeal or request to employers so that workers and companies 
become participants in the labor social security program because basically social security Labor is the right of the workforce. Meanwhile, the Government, in this case the Ministry of Manpower, has a very important role, namely to supervise the implementation of the provisions of the applicable laws and regulations. the organizer of the labor social security program. From the facts in the field, the low trend of participation in the labor social security program is due to employers who do not want to comply with the regulations for registering workers and companies. In addition to this, the government also seeks to provide guidance to workers and entrepreneurs so that workers have knowledge of labor social security and entrepreneurs have legal awareness to comply with existing laws and regulations, so that in the end the protection of the implementation of labor social security for workers. The specified period of employment agreement (PKWT) can be realized.

In carrying out social security services which basically provide protection and create welfare for workers with a Specific Time Work Agreement (PKWT), as the implementing agency for the labor social security program, of course PT Jamsostek (Persero) has obstacles in its implementation. The obstacle that is often faced by PT Jamsostek (Persero) is finding entrepreneurs who do not want to register their workers and companies as participants in the social security program for workers. while PT Jamsostek (Persero) does not have the authority to force entrepreneurs to register companies and their workers as participants in the Jamsostek program because it is the authority of the Government which in this case is carried out by the Ministry of Manpower in charge of manpower, to carry out the rule of law for every legal subject who violates it. The capacity of PT Jamsostek (Persero) is limited only as the organizing body for the Jamsostek program

\section{References}

Relations. RajaGrafindo Persada. 2007

Asyhadie, Zaeni, SH, M. Hum. Legal Aspects of Labor Social Security.

Raja Grafindo Persada. 2008.

Budiono, Abdul Rachman, SH, MH Labor Law in Indonesia. Jakarta: RajaGrafindo Persada. 1999.

Djumadi, SH Labor Law Work Agreement. Jakarta: PT RajaGrafindo Persada. 2002.

Husni, Lalu, SH, M. Hum. Introduction to Indonesian Labor Law. Jakarta: RajaGrafindo Persada. 2001.

Jehani, Liberty. Workers' rights when laid off. Jakarta: Visimedia. 2001.

Khakim, Abdul, SH Labor Law in Indonesia: Based on Law Number 13 Year 2003. Bandung: Citra Aditya Bakti. 2003.

Lanny Ramli, Jamsostek in Indonesia, Airlangga University Press, Surabaya, 1997 Muharam, Hidayat, SH Guide to Understanding Labor Law and Implementation in Indonesia. Bandung: Image of Aditya Bakti. 2006.

Maimun, SH, S.Pd. Employment Law An Introduction. Jakarta: Pradnya Paramita. 2004.

PT Jamsostek (Persero), Collection of Laws and Regulations for the Jamsostek Program: Guidelines for the Implementation of the Social Security Program for Workers, 2007.

PT Jamsostek (Persero), Principles and Practices of Social Security for Workers, 2007 Ridwan Halim, Sari Actual Labor Law, Jakarta : Pradnya Paramita, 1987.

Ridwan Marpaung, Popular Dictionary of Social Workers, 1998. 
Sunggono, Bambang, SH, MS Legal Research Methods. Jakarta: Raja Grafindo Persada. 2006.

Supomo, Iman, Prof., SH. Labor Law in the Field of Employment Relations. Jakarta: Bridge. 2001.

Supomo, Iman, Prof., SH. Labor Law in Occupational Health Sector. Jakarta: Pradnya Paramita. 1975.

Supomo, Iman, Prof., SH. Introduction to Labor Law. Jakarta: Bridge. 2001.

1945 Constitution of the Republic of Indonesia The Civil Code.

Law Number 3 of 1992 concerning Labor Social Security Law Number 13 of 2003 concerning Manpower.

Law Number 40 of 2004 concerning the National Social Security System Regulations Government Republic Indonesia Number 14 Year 1993 About Implementation of the Labor Social Security Program.

Government Regulation Number 36 of 1995 concerning the Establishment of the Organizing Agency for the Social Security Program for Workers.

Government Regulation of the Republic of Indonesia Number 76 of 2007 concerning the Fifth Amendment to Government Regulation of the Republic of Indonesia Number 14 of 1993 concerning the Implementation of the Social Security Program for Workers.

Decree of the Minister of Manpower Number KEP-150/MEN/1999 concerning the Implementation of the Labor Social Security Program for Casual Daily Workers, Wholesale and Specific Time Work Agreements.

Regulation of the Minister of Manpower of the Republic of Indonesia Number PER-05/MEN/1993 concerning Technical Guidelines for Participation Registration, Payment of Contributions, Payment of Compensation, and Social Security Services for Workers.

Dr. Todung Mulia Lubis. Upholding Human Rights Claiming Discrimination.

Presented at the 55th Anniversary of USU Faculty of Law, February 14, 2009.

Mitar Pelawi, SH, MM : Termination of Employment. Delivered in a Public Lecture at the USU Faculty of Law on February 22, 2008.

Tambunan, Helman, SH, "Empowering Social Security, Moral Responsibility for the Prosperity of the Nation's Life": Articles submitted in the PT Jamsostek/Jamsostek Journalism Award 2008 Writing Competition. Sinar Indonesia Baru Daily, Wednesday, November 12, 2008. 